\title{
End of the 2018 year: reflections and thanks
}

\author{
L. A. Harvey ${ }^{1}$ \\ ๑) International Spinal Cord Society 2018
}

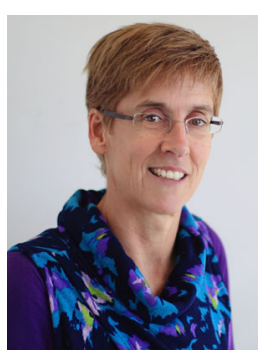

December 2018 marks the end of my second year as Editorin-Chief for Spinal Cord. So I want to take this opportunity to thank many people and to reflect on where we are.

First, and foremost, I want to acknowledge, you, the reader. A journal is only as strong as its readership. I hope that you will continue to read the journal, submit your manuscripts to the journal, and discuss the journal's contents with your colleagues. With your support Spinal Cord will continue to be the most important and influential journal in the area of spinal cord injuries and disorders. This is appropriate given Spinal Cord is the official journal and flagship of The International Spinal Cord Society (ISCoS).

Secondly, I want to thank the journal's loyal and dedicated reviewers, especially those of you who review regularly for the journal (see here [1] for a list of reviewers for 2017). Some review to learn from their co-reviewers and the responses of authors to comments. Others review out of a sense of obligation to the discipline. And many review because they want to play a part in ensuring that high quality papers are published in Spinal Cord. Regardless of motivation, reviewers give selflessly of their time and expertise. The papers that we publish are much stronger for rigorous review. So on behalf of everyone associated with the journal, including authors, I thank you.

Thirdly, I want to publicly thank the Associate Editors (Marcel Post, Sonja de Groot, John Steeves, Marcel Dijkers, and Masaya Nakamura) and the Editorial Board. The Associate Editors and Editorial Board members work tirelessly behind the scenes reviewing papers; providing me with advice; promoting the journal's contents on social media; and soliciting, managing, and editing manuscripts. To all of you, I offer my sincere thanks.

Congratulations to the recipients of Spinal Cord's prizes for last year: 2017. They were:

\footnotetext{
$\triangle$ L. A. Harvey

spinalcord@iscos.org.uk

1 University of Sydney, Sydney, Australia
}

Readers' choice for best review paper (based on most downloads in the first 6 months after publication):

Sharif-Alhoseini M, Khormali M, Rezaei M, Safdarian M, Hajighadery A, Khalatbari MM. et al. Animal models of spinal cord injury: a systematic review. Spinal Cord 2017; 55: 714.

Readers' choice for best original research papers (based on most downloads in the first 6 months after publication):

Zbogar D, Eng JJ, Miller WC, Krassioukov AV, Verrier MC. Movement repetitions in physical and occupational therapy during spinal cord injury rehabilitation. Spinal Cord 2017; 55: 172.

Best review paper (judged by the Associate Editors):

Shamout S, Biardeau X, Corcos J, Campeau L. Outcome comparison of different approaches to self-intermittent catheterization in neurogenic patients: a systematic review. Spinal Cord 2017; 55: 629.

Best original research paper ((judged by the Associate Editors):

Savic G, DeVivo MJ, Frankel HL, Jamous MA, Soni BM, Charlifue S. Causes of death after traumatic spinal cord injury —a 70-year British study. Spinal Cord 2017; 55: 891.

Lastly, I want to sincerely thank Dr Sally Halsall who recently left Spinal Cord. Sally worked as the Journal Manager for three years and was the face of the journal for most reviewers and authors. She has done a wonderful job. On a similar note I want to acknowledge staff from Springer Nature, particularly Virginia Mercer and Tasnia Nizam. They oversee timely production of the journal.

These are good times for Spinal Cord. The journal's Impact Factor rose to 1.936, and the quality of submissions is steadily improving. The acceptance rate is currently sitting on $\sim 40 \%$ - not too low and not too high. The editorial focus has been on fairness, transparency, and clear communication of high quality science. We hope that, with the focus on these three key pillars, the quality of research published in Spinal Cord will continue to improve.

\section{Reference}

1. Reviewer recognition. Spinal Cord 2018; 56: 1018-1019. 